\title{
Saline water and nitrogen doses in the cultivation of West Indian cherry in the post-grafting phase
}

\author{
Francisco Wesley Alves Pinheiro' ${ }^{\circledR}$, Geovani Soares de Lima ${ }^{2 *}{ }^{\circledR}$, Hans Raj Gheyi ${ }^{3}$,

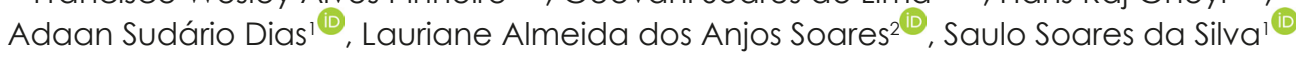 \\ 'Federal University of Campina Grande, Campina Grande, Brazil \\ ${ }^{2}$ Federal University of Campina Grande, Pombal, Brazil \\ ${ }^{3}$ Federal University of Recôncavo da Bahia, Cruz das Almas, Brazil \\ *Corresponding author, e-mail: geovani.soares@pq.cnpq.br
}

\begin{abstract}
This study aimed to evaluate the photosynthetic pigments and growth of the West Indian cherry cV. BRS 366 Jaburu in the post-grafting phase as a function of the salinity levels of the irrigation water and nitrogen fertilization under greenhouse conditions, in the municipality of Campina Grande-PB. The study was performed in randomized blocks, consisting of two levels of electrical conductivity of irrigation water - ECW (0.8 and 4.5 $\left.\mathrm{dS} \mathrm{m}^{-1}\right)$ and four nitrogen doses $(70,85,100$, and $115 \%$ of the recommended dose for the crop), with three replications. The synthesis of chlorophyll $a$ and carotenoids in the West Indian cherry plants was inhibited with ECW of $4.5 \mathrm{dS} \mathrm{m}^{-1}$. Nitrogen fertilization in the estimated doses of 92 and $80 \%$ of $\mathrm{N}$ reduced the effects of salt stress on the contents of chlorophyll $a$ and $b$ in West Indian cherry plants, at 630 days after transplanting. The increment in nitrogen fertilization increases quadratically the absolute and relative growth rate of the diameter in the rootstock of the West Indian cherry plants under irrigation with saline waters.
\end{abstract}

Keywords: Malphigia emarginata, nitrogen doses, salinity

\section{Introduction}

The West Indian cherry (Malpighia emarginata DC.) grows in tropical and subtropical climates and, therefore, its cultivation is performed in practically the entire territory of Brazil, with the Northeast region standing out in the cultivation of this species. It is estimated that 10.000 ha of cultivated area with this plant exists in Brazil and that the states of Bahia, Ceará, Paraíba, and Pernambuco are responsible for more than $50 \%$ of the entire national production (Santos, 2019). In this context, the cultivar BRS 366-Jaburu stands out for its high productivity and high content of vitamin C, having originated through rigorous selection from an orchard with seed-propagated plants, in the municipality of Jaguaruana, CE (EMBRAPA, 2012).

It is considered an adapted fruit species to the edaphoclimatic conditions of Northeastern Brazil. However, this region presents limitations involving quantitative and qualitative aspects regarding the existing water resources, especially concerning the presence of high salt concentrations in the water (Souto et al., 2013).

In this region, most water sources present high salt contents, with electrical conductivity up to $5.0 \mathrm{dS} \mathrm{m}^{-1}$, or more. High salt levels potentialize the problem of soil salinization, causing severe damage to the crops (Lima et al., 2018). The main restrictions of salt stress to the plants include decreased osmotic potential, the toxicity of specific ions, and nutritional imbalance. These effects result in severe modifications in plant metabolism, altering physiological and biochemical processes (Farooq et al., 2015). In spite of the risks imposed by salt stress, irrigation with brackish water is increasingly necessary, given the limitation of water resources associated with the negative water balance occurring in important phases of the crop cycles (Aydin et al., 2012). 
In the productive process, besides the importance of waterusage in quantity and quality, fertilization emerges as a preponderant factor in order to obtain a positive result. Among the macronutrients demanded by plants, nitrogen $(\mathrm{N})$ is one of the most important for performing a structural function. It is part of several organic compounds that are vital for the plant, such as amino acids, proteins, chlorophyll, nucleic acids (Taiz \& Zeiger, 2013), and other important biomolecules, such as ATP, NADH, NADPH, and several enzymes. Organic compounds can increase the adjustment capacity of the plants to salinity, imposing a greater resistance to salt stress (Munns et al., 2020).

In this context, this study aimed to evaluate the photosynthetic pigments and growth of the West Indian cherry cv. 'BRS 366 Jaburu' irrigated with brackish waters and nitrogen doses.

\section{Material and Methods}

The research was performed in protected environment conditions (greenhouse) at the Center of Technology and Natural Resources of Federal University of Campina Grande (CTRN/UFCG), located in the municipality of Campina Grande, PB, having the local geographic coordinates $7^{\circ} 15^{\prime}$ ' 18' ' latitude S, 3552' 28', longitude $\mathrm{W}$, and elevation of $550 \mathrm{~m}$.

The experimental design was in randomized blocks, with three replications, using a $2 \times 4$ factorial arrangement whose treatments consisted of two levels of electrical conductivity of the irrigation water - ECW (0.8 and $\left.4.5 \mathrm{dS} \mathrm{m}^{-1}\right)$ and four nitrogen doses $(70,85,100$, and $115 \%$ of the recommendation of Cavalcanti (2008)), and one plant per plot. The dose referring to $100 \%$ corresponded to $200 \mathrm{~g}$ of $\mathrm{N}$ per plant year-1.

The high-salinity irrigation water was prepared by dissolving the $\mathrm{NaCl}, \mathrm{CaCl}_{2} \cdot 2 \mathrm{H}_{2} \mathrm{O}$, and $\mathrm{MgCl}_{2} \cdot 6 \mathrm{H}_{2} \mathrm{O}$ salts in the equivalent proportion of $7: 2: 1$, respectively, in supply water ( $E C W=1.40 \mathrm{dS} \mathrm{m}^{-1}$ ) from the municipality of Campina Grande, PB, based on the ratio between the ECW and salt concentration $\left(\mathrm{mmol}_{\mathrm{C}} \mathrm{L}^{-1}=10^{*} \mathrm{ECW} \mathrm{dS} \mathrm{\textrm {m } ^ { - 1 } )}\right.$ extracted from Richards (1954). The water with the lowest electrical conductivity $\left(0.8 \mathrm{dS} \mathrm{m}^{-1}\right)$ was obtained through the dilution of supply water with rainwater $(E C W=0.02 \mathrm{dS}$ $\left.\mathrm{m}^{-1}\right)$.

The plants were cultivated in drainage lysimeters filled with $250 \mathrm{~kg}$ of a previously ground Regolithic Neosol (Psamments)with sandy-loam texture, from the countryside of the municipality of Esperança, PB, whose chemical and physical characteristics were obtained according to the methodologies proposed by Teixeira et al. (2017): $\mathrm{Ca}^{2+}=9.07 \mathrm{cmol}_{\mathrm{C}} \mathrm{kg}^{-1} ; \mathrm{Mg}^{2+}=2.78 \mathrm{cmol}_{\mathrm{c}} \mathrm{kg}^{-1}$;
$\mathrm{Na}^{+}=1.64 \mathrm{cmol}_{\mathrm{c}} \mathrm{kg}^{-1} ; \mathrm{K}^{+}=0.23 \mathrm{cmol}_{\mathrm{c}} \mathrm{kg}^{-1} ; \mathrm{H}^{+}+\mathrm{Al}^{3+}=8.61$ $\mathrm{cmol}_{\mathrm{C}} \mathrm{kg}^{-1} ; \mathrm{Al}^{3+}=0 \mathrm{cmol}_{\mathrm{c}} \mathrm{kg}^{-1} ; \mathrm{CTC}=22.33 \mathrm{cmol}_{\mathrm{c}} \mathrm{kg}^{-1}$; organic matter $=2.93 \mathrm{dag} \mathrm{kg}^{-1} ; \mathrm{P}=39.8 \mathrm{mg} \mathrm{kg}^{-1} ; \mathrm{pH}$ in water $(1: 2.5)=5.58$; electrical conductivity of the soil saturation extract $=2.15 \mathrm{dS} \mathrm{m}^{-1} ; \mathrm{SAR}=0.67\left(\mathrm{mmol} \mathrm{L}^{-1}\right)^{0,5}$; percentage of exchangeable sodium $=7.34$; sand $=$ $659.9 \mathrm{~g} \mathrm{~kg}^{-1}$; silt $=161.2 \mathrm{~g} \mathrm{~kg}^{-1}$; clay $=178.9 \mathrm{~g} \mathrm{~kg}^{-1}$; moisture at $33.42 \mathrm{kPa}=25.91 \mathrm{dag} \mathrm{kg}^{-1}$; moisture at $1519.5 \mathrm{kPa}=$ $12.96 \mathrm{dag} \mathrm{kg}^{-1}$.

In the bottom of each lysimeter, a layer of fine gravel was placed and a drain was installed using a $4 \mathrm{~mm}$ tube to drain the excess water, connected to a container for the evaluation of the drained water and later determination of water intake by the plants. The extremity of the drain in the interior of the lysimeter was wrapped with a non-woven geotextile fabric (Bidim OP 30) to avoid obstruction by soil material.

The West Indian cherry seedlings used as rootstocks in this study were produced by Embrapa Agroindústria Tropical, in Pacajus-CE. The scion variety was the cV. BRS 366 Jaburu, given its high productivity (EMBRAPA, 2012).

Before the transplanting of the West Indian cherry seedlings, the soil moisture content was raised until reaching field capacity. The seedlings were transplanted at 240 days after grafting. During the acclimatization period at the plant nursery (30 days after transplanting), the seedlings were daily irrigated with low-salinity water (0.8 dS $\mathrm{m}^{-1}$ ) by applying, in each lysimeter, a sufficient water volume as to maintain soil moisture close to field capacity, with the volume applied being determined according to the water demand of the plants, estimated by the following water balance: applied volume minus the volume drained in the previous irrigation, adding a lixiviation fraction of $10 \%$.

The fertilization with phosphorus and potassium was performed according to the recommendation by Cavalcanti (2008), divided into 12 equal monthly applications. In order to supply the need for micronutrients in this crop, a Ubyfol ${ }^{\circledR}$ solution was applied weekly via foliar spraying on the adaxial and abaxial surfaces, containing $1.5 \mathrm{~g} \mathrm{~L}^{-1}\left[\left(\mathrm{~N}\right.\right.$ (15\%); $\mathrm{P}_{2} \mathrm{O}_{5}$ (15\%); $\mathrm{K}_{2} \mathrm{O}$ (15\%); Ca (1\%); $\mathrm{Mg}$ (1.4\%); S (2.7\%); Zn (0.5\%); B (0.05\%); Fe (0.5\%); Mn (0.05\%); Cu $(0.5 \%)$; Mo (0.02\%)].

The contents of carotenoids (Car) and chlorophyll $a(\mathrm{Cl} a)$ and $b(\mathrm{Cl} b)$ were evaluated at 630 days after transplantation (DAT), following the laboratory methods developed by Arnon (1949). Five discs from the leaf blade of the third mature leaf from the apex of the quaternary branch were used. Based on the extracts, 
the concentrations of chlorophyll and carotenoids in the solutions were determined in a spectrophotometer in the absorbance wavelength (ABS) $(470,646$, and $663 \mathrm{~nm})$, through Eq. 1, 2, and 3:

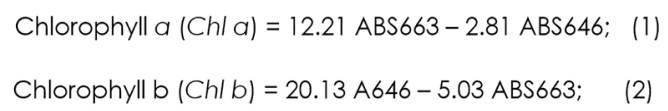

Total carotenoids (Car) $=(1000$ ABS470 $-1.82 \mathrm{Chl} \mathrm{a}-85.02 \mathrm{Chl} \mathrm{b}) / 198$

The values obtained for the contents of chlorophyll $a, b$, and carotenoids in the leaves were expressed in $\mathrm{mgg}^{-1}$ of fresh matter (FM).

Plant growth was measured in the period from 303 to 650 DAT through absolute and relative growth rates of the graft diameter (AGRGD and RGRGD), grafting point (AGRGP and RGRGP), and rootstock diameters (AGRRD and RGRRD).

The determination of the absolute growth rate (AGR) was obtained by employing the methodology proposed by Benincasa (2003), as described in Eq. 4:

$\operatorname{AGR}=\frac{\left(A_{2}-A_{1}\right)}{\left(t_{2}-t_{1}\right)}$

In which: $A G R=$ absolute growth rate;

$A_{2}=$ stem diameter at time $t_{2}$;

$A_{1}=$ stem diameter at time $t_{1}$; and

$t_{2}-t_{1}=$ time interval between samplings.
The relative growth rates (RGR) were obtained through Eq. 5, which measures growth as a function of the preexisting matter, adapting the procedure contained in Benincasa et al. (2003) to plant diameter.

$$
\mathrm{RGR}=\frac{\left(\ln \mathrm{A}_{2}-\ln \mathrm{A}_{1}\right)}{\left(\mathrm{t}_{2}-\mathrm{t}_{1}\right)}
$$

In which: $R G R$ = relative growth rate;

$A_{2}=$ stem diameter at time $t_{2}$;

$A_{1}=$ stem diameter at time $t_{1}$;

$t_{2}-t_{1}=$ time interval between measurements, and In = natural logarithm.

The data obtained were subjected to analysis of variance by the ' $F$ ' test, at the $p \leq 0.05$ and $p \leq 0.01$ levels of probability. In the case of significance, Tukey's test was performed for the water salinity levels, along with regression analysis for the nitrogen doses factor, using the SISVAR software for statistical analyses (Ferreira, 2014).

\section{Results and Discussion}

According to the result of the analysis of variance (Table 1), it is verified that water salinity significantly influenced the chlorophyll $a$ and carotenoids variables. The nitrogen doses provided a significant effect for chlorophyll $a$ and $b$ in the West Indian cherry plants. There was no significant interaction between treatments (saline levels $x$ nitrogen doses) on the studied variables, at 630 days after transplanting.

Table 1. Summary of the analysis of variance referring to the contents of chlorophyll $a(\mathrm{Chl} a)$ and $b$ (Chl b) and carotenoids (Car) of the 'BRS 366 Jaburu' West Indian cherry plants irrigated with waters of different salinities and nitrogen doses, at 630 days after transplantation.

\begin{tabular}{|c|c|c|c|c|}
\hline \multirow{2}{*}{ Source of variation } & \multirow{2}{*}{ GL } & \multicolumn{3}{|c|}{ Mean squares } \\
\hline & & Chl a & Chl b & Car \\
\hline Saline levels (SL) & 1 & $0.0425^{*}$ & $0.0077^{\text {ns }}$ & $613.2726^{*}$ \\
\hline Nitrogen doses (ND) & 3 & $0.0995^{* *}$ & $0.0134^{*}$ & $357.7103^{\text {ns }}$ \\
\hline Interaction (SL x ND) & 3 & $0.1008^{\text {ns }}$ & $0.0123^{\text {ns }}$ & $341.6898^{\mathrm{ns}}$ \\
\hline Blocks & 2 & $0.0021^{\mathrm{ns}}$ & $0.0019^{\text {ns }}$ & $75.8317^{\text {ns }}$ \\
\hline Residual & 14 & $0.0085^{\text {ns }}$ & $0.0040^{\text {ns }}$ & $149.4597^{\text {ns }}$ \\
\hline $\mathrm{CV}(\%)$ & & 12.34 & 28.76 & 21.49 \\
\hline
\end{tabular}

The synthesis of chlorophyll a $(\mathrm{Chl} a)$ in the West Indian cherry was negatively influenced by the increase in the salinity of the irrigation water and, according to the test of means (Figure 1A), it is seen that the plants irrigated with water with electrical conductivity of $0.8 \mathrm{dSm}^{-1}\left(0.7933 \mathrm{mg} \mathrm{g}^{-1} \mathrm{FM}\right)$ obtained a higher content of $\mathrm{Chl}$ a by $11.87 \%$ compared to the plants irrigated with water of $4.5 \mathrm{dS} \mathrm{m}^{-1}\left(0.7091 \mathrm{mg} \mathrm{g}^{-1} \mathrm{FM}\right)$. Regarding the negative effects caused by the increase in the electrical conductivity of the irrigation water on the synthesis of photosynthetic pigments, the declines in the chlorophyll contents, according to (Pereira Filho et al., 2019), are the result of imbalances in the physiological and biochemical activities promoted by the salt content when beyond the limite of salt tolerace of the crop. For the respective authors, excess of salt stimulates the enzymatic activity of chlorophyllase, which degrades the molecules of the photosynthetic pigment and induces the structural destruction of the chloroplasts, also resulting in the imbalancing and loss of activity by the pigmentation proteins.

According to the means comparison test (Figure 1B), it is verified that the content of carotenoids in the West Indian cherry plants subjected to irrigation with water of 

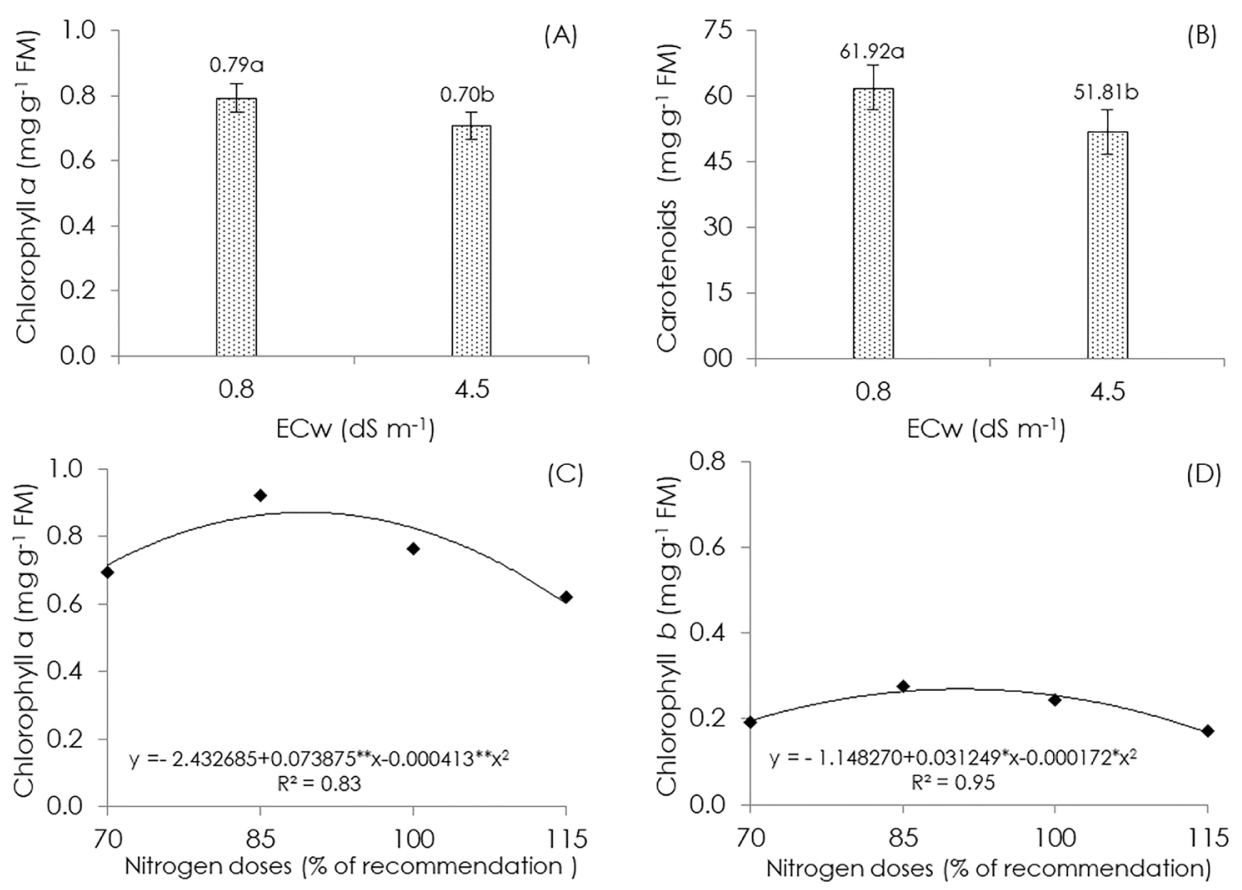

Figure 1. Contents of chlorophyll a (A) and carotenoids (B) of the BSR 366 Jaburu West Indian cherry as a function of the salinity of the irrigation water - ECW and contents of chlorophyll a (C) and chlorophyll b (D), as a function of nitrogen doses, the at 630 days after transplanting. Bars represent the standard error of the mean $(n=3)$. Mean with different letter indicates that the treatments differed from each other by Tukey's test, $\mathrm{p}<0.05$.

$0.8 \mathrm{dS} \mathrm{m}^{-1}$ statistically differed from the plants cultivated under the highest ECW level (4.5 dS $\mathrm{m}^{-1}$ ), about $19.51 \%$ (10.11 $\left.\mathrm{mg} \mathrm{g}^{-1} \mathrm{FM}\right)$ more in comparison to the values of the plants irrigated with ECW of $0.8 \mathrm{dS} \mathrm{m}^{-1}$. According to Gomes et al. (2011), salt stress leads to the degradation of beta-carotene, providing a decrease in the content of carotenoids. This fact was observed in yellow passion fruit by Freire et al. (2013), whose treatment with salinized water $\left(4.5 \mathrm{dS} \mathrm{m}^{-1}\right)$ reduced the contents of carotenoids, the depressive effects of salts being mitigated by the application of biofertilizer and topdressing; therefore, the reduction in the content of carotenoids may have implied in increased chlorophyll sensibility, causing their degradation.

The nitrogen doses promoted a quadratic effect on the contents of $\mathrm{Chl} a$ and $\mathrm{Chl} b$, at 630 DAT. According to the regression equations (Figures $1 C$ and $D$ ), the maximum estimated values were 0.8708 and 0.2711 $\mathrm{mg} \mathrm{g}^{-1} \mathrm{FM}$, respectively, for $\mathrm{Chl} a$ and $b$, obtained when the plants received the doses of 89 and $91 \%$ of the $N$ recommendation. Nitrogen, in proper concentrations, is fundamental for the better development of physiological and biochemical activities and plant growth. In that perspective, $\mathrm{N}$ performs its roles as a structural component of macromolecules and constituent of several enzymes, forming amino acids, amides, proteins, precursors of coenzymes of plant hormones, chlorophylls, nucleic acids, and nucleotides (Taiz \& Zeiger, 2013).
There was a significant effect of the interaction between factors (NS $\times$ ND) for the relative and absolute growth rates of the diameter at the grafting point and in the rootstock $\left(A G R_{R D}\right.$ and $R G R_{R D}$ ) (Table 2). The salt levels factor significantly influenced all analyzed variables, except the absolute growth rate of the diameter at the grafting point $\left(A G R_{G P}\right)$ and in the rootstock $\left(A G R_{R D}\right)$. The nitrogen doses promoted a significant effect on all variables, except for the relative and absolute growth rates of the rootstock $\left(R G R_{R D}\right.$ and $\left.A G R_{R D}\right)$ of the $B R S$ Jaburu West Indian cherry plants, at 630 days after transplantation.

The increase in the $\mathrm{N}$ doses negatively affected the $R G R_{G D}$, and through the regression equation (Figure 2A) a linear decreasing effect can be noted, with a decrease of $0.000004 \mathrm{~mm} \mathrm{~mm}^{-1} \mathrm{~d}^{-1}(0.33 \%)$ per unitary increment in fertilization. A decrease of $19.56 \%$ is verified when comparing the West Indian cherry plants fertilized with $115 \%$ of $\mathrm{N}$ with plants that received $70 \%$ of the recommendation. Some studies, investigating the effect of nitrogen fertilization in West Indian cherry plants, demonstrated that $\mathrm{N}$ is one of the main nutrients demanded by the crop, favoring growth and promoting the indirect accumulation of other nutrients, that is, when resulting from an adequate dose. High $\mathrm{N}$ doses compromise nutritional balance and, as a consequence, influence plant growth (Esashika et al., 2013; Ferreira et al., 2014). 
Table 2. Summary of the analysis of variance referring to the absolute and relative growth rates of the graft diameter $\left(A G R_{G D}\right.$ and $\left.R G R_{G D}\right)$, grafting point $\left(A G R_{G P}\right.$ and $\left.R G R_{G P}\right)$, and rootstock $\left(A G R_{R D}\right.$ and $\left.R G R_{R D}\right)$ of West Indian cherry plants irrigated with waters of different salinities and nitrogen doses, in the period from 303 to 650 days after transplanting.

\begin{tabular}{|c|c|c|c|c|c|c|c|}
\hline \multirow{2}{*}{ Source of variation } & \multirow{2}{*}{ DF } & \multicolumn{6}{|c|}{ Mean squares } \\
\hline & & $R G R_{G D}$ & $R G R_{G P}$ & $R G R_{R D}$ & $A G R_{G D}$ & $A G R_{G P}$ & $A G R_{R D}$ \\
\hline Saline levels (SL) & 1 & $3.6753^{* * *}$ & $5.5815^{* *}$ & $1.4106^{* *}$ & $0.000071^{* *}$ & $0.000024^{\mathrm{ns}}$ & $0.000011^{\mathrm{ns}}$ \\
\hline Nitrogen doses (ND) & 3 & $7.4015^{*}$ & $1.5063^{* *}$ & $1.0144^{\mathrm{ns}}$ & $0.000031^{*}$ & $0.000066^{* *}$ & $0.000015^{\mathrm{ns}}$ \\
\hline Interaction (SL x ND) & 3 & $2.8804^{\text {ns }}$ & $1.3410^{* *}$ & $5.7144^{*}$ & $0.000022^{\text {ns }}$ & $0.000112^{* *}$ & $0.000043^{* *}$ \\
\hline Blocks & 2 & $4.2769^{\text {ns }}$ & $5.0204^{\mathrm{ns}}$ & $1.8666^{\mathrm{ns}}$ & $0.000002^{\text {ns }}$ & $0.000021^{\text {ns }}$ & $0.000004^{\mathrm{ns}}$ \\
\hline Residual & 14 & $2.2769^{\text {ns }}$ & $2.4556^{\text {ns }}$ & $1.3804^{\text {ns }}$ & $0.000010^{\text {ns }}$ & $0.000011^{\mathrm{ns}}$ & $0.000005^{\text {ns }}$ \\
\hline CV (\%) & & 16.38 & 18.31 & 13.40 & 14.24 & 14.66 & 9.14 \\
\hline
\end{tabular}

$\mathrm{ns},{ }^{*},{ }^{* *}$ respectively not significant, significant at $\mathrm{p} \leq 0.05$, and $\mathrm{p} \leq 0.01$.
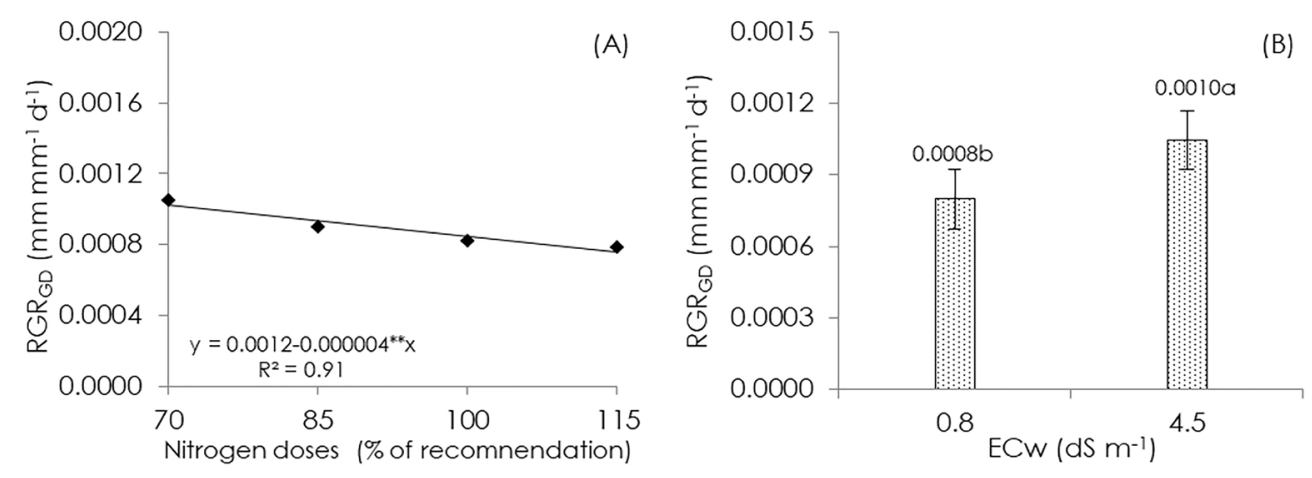

Figure 2. Relative growth rate of the graft diameter - RGR of the BRS 366 Jaburu West Indian cherry as a function of nitrogen doses (A) and salinity levels of the irrigation water - ECW (B), in the period from 303 to 650 days after transplanting.

Bars represent the standard error of the mean $(n=3)$. A mean with different letter indicates that the treatments differed from each other by Tukey's test, $\mathrm{p}<0.05$.

According to the means comparison test (Figure $2 B$ ), it was verified that the West Indian cherry plants under irrigation with $\mathrm{ECW}$ of $4.5 \mathrm{dS} \mathrm{m}^{-1}$ differed statistically from the plants under water salinity of $0.8 \mathrm{dS} \mathrm{m}^{-1}$, with an increase in the $R G R_{G D}$ of $0.0002 \mathrm{~mm} \mathrm{~mm}^{-1} \mathrm{~d}^{-1}$ in the plants irrigated with water of $4.5 \mathrm{dS} \mathrm{m}^{-1}$, compared to the plants

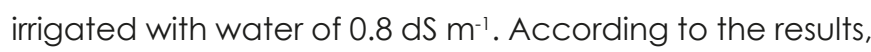
it may be inferred that an osmotic adjustment occurred, allowing, in salt stress conditions, that the accumulation of absorbed ions could occur in the cytoplasm and the organelles, in low levels, so that no interference would occur with the enzymatic and metabolic mechanisms and with the hydration of proteins in the cells (Assaha et al., 2017). Likewise, it may be related to the synthesis and accumulation of organic solutes in the cytoplasm, promoting the osmotic adjustment and favoring the maintenance of the turgor pressure and cell volume under salt stress conditions, ensuring plant growth (Oliveira et al., 2011).

The effects of the interaction between saline levels and nitrogen doses on the relative growth rate of the diameter at the grafting point $\left(R G R_{G P}\right)$ and in the rootstock $\left(R G R_{R D}\right)$ of the West Indian cherry plants can be observed in Figure 3. Regarding the $R G R_{G P^{\prime}}$ it is seen that according to the regression equation (Figure $3 \mathrm{~A}$ ), the data adjusted to the linear model, whose increment obtained in the $R G R_{G P}$ of the plants inigated with the water of lowest salinity $\left(0.8 \mathrm{dS} \mathrm{m}^{-1}\right)$ was $23.12 \%\left(0.000175 \mathrm{~mm} \mathrm{~mm}^{-1} \mathrm{~d}^{-1}\right)$ compared to those that received $\mathrm{N}$ doses of $115 \%$ in relation to those subjected to a $70 \%$ dose. However, when the plants were irrigated with water of $4.5 \mathrm{dS} \mathrm{m}^{-1}$, a reduction in the $R G R_{G P}$ was observed with the increase in the nitrogen doses from $70 \%$ of the $\mathrm{N}$ recommendation, with a decrease of $17.43 \%\left(0.0001813 \mathrm{~mm} \mathrm{~mm}^{-1} \mathrm{~d}^{-1}\right.$ in the $R G R_{G P}$ in relation to the highest $\mathrm{N}$ dose (115\%).

Regarding the $\mathrm{RGR}_{\mathrm{RD}^{\prime}}$ an adjustment of the data to the quadratic model is verified (Figure 3B), in which it is observed that the plants irrigated with low-salinity water $\left(0.8 \mathrm{dS} \mathrm{m}^{-1}\right)$ obtained the maximum estimated value of $0.0009055 \mathrm{~mm} \mathrm{~mm}^{-1} \mathrm{~d}^{-1}$ in the estimated dose of $94 \%$ of the $\mathrm{N}$ recommendation. From this dose up, there was a decrease in the $R G R_{R D}$ of the West Indian cherry plants. When the plants were irrigated with water of 4.5 dS $\mathrm{m}^{-1}$, it was observed that from the $101 \%$ dose there was a reduction in the $R G R_{R D}$. According to Sousa et al. (2011), these reductions are related to the decrease in water availability or excessive accumulation of $\mathrm{Na}^{+}$and $\mathrm{Cl}^{-}$in the plant tissues, affecting essential physiological processes for plant growth and development. 
According to the regression equation (Figure $4 A)$ referring to the absolute growth rate of the graft diameter $\left(A G R_{G D}\right)$, it is verified that there was a decrease in this value as the $\mathrm{N}$ doses increased. The reduction was
$4.64 \%$ per each $15 \%$ increase of $\mathrm{N}$, in the period from 303 to 650 days after transplanting. The West Indian cherry plants fertilized with the highest $\mathrm{N}$ dose (115\%) presented a decline in the $A G R_{G D}$ of $18.86 \%$ when compared to the
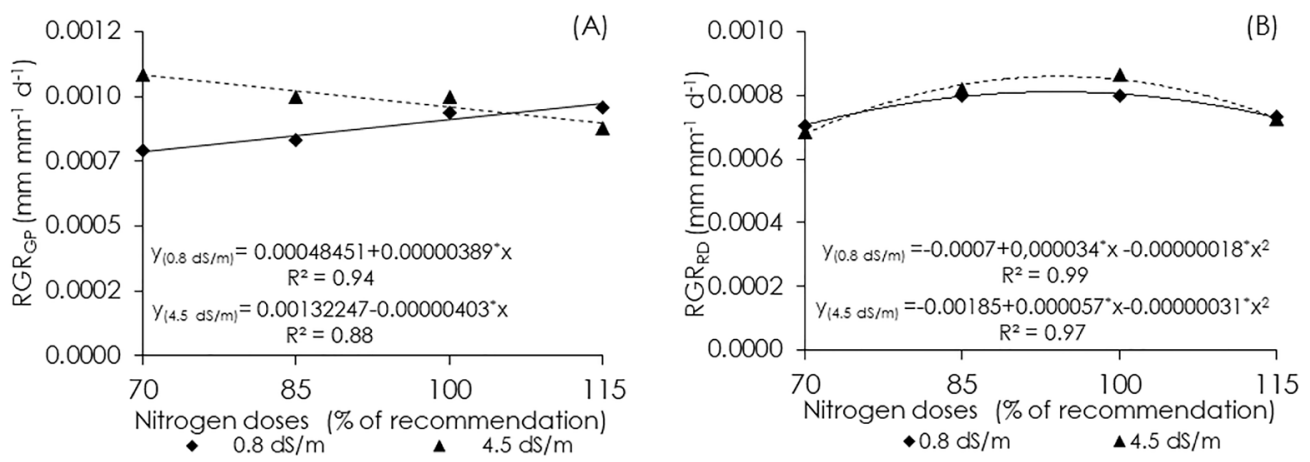

Figure 3. Relative growth rate of the diameter at the grafting point- $R G R_{G P}(A)$ and in the rootstock - $R G R_{R D}$ (B) of the BRS 366 Jaburu West Indian cherry as a function of the interaction between water salinity levels - ECW and nitrogen doses, in the period from 303 to 650 days after transplantation.

plants fertilized with the lowest nitrogen dose applied (70\%). When in excess, it may induce the deficiency or excessive accumulation of other nutrients, leading to a nutritional imbalance that can affect plant growth (Taiz \& Zeiger, 2013). In these conditions, high doses of fertilizers, including nitrogen fertilizers, which also contain salts, increase soil salinity and compromise plant growth (Chen et al., 2010).
Through the means comparison test (Figure 4B) it is verified that the West Indian cherry plants irrigated with water with electrical conductivity of $4.5 \mathrm{dS} \mathrm{m}^{-1}$ presented a $A G R_{G D}$ statistically above $\left(0.023 \mathrm{~mm} \mathrm{~d}^{-1}\right)$ that of the plants under the lowest saline level $\left(0.020 \mathrm{~mm} \mathrm{~d}^{-1}\right)$, with a reduction of $13.04 \%$. The absolute growth rate of the diameter at the grafting point $\left(A G R_{G P}\right)$ and in the rootstock $\left(A G R_{R D}\right)$ of the West Indian cherry plants were
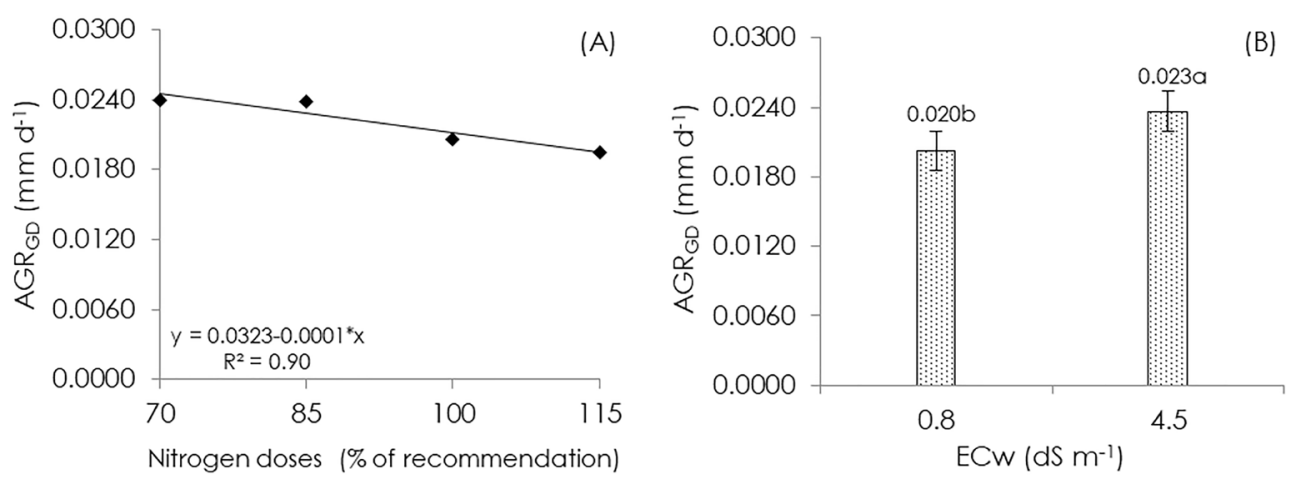

Figure 4. Absolute growth rate of the graft diameter - $A G R_{G D}$ of the BRS 366 Jaburu West Indian cherry plants as a function of the nitrogen doses (A) and salinity levels of the irrigation water ECW (B), in the period from 303 to 650 days after transplantation.

Bars represent the standard error of the mean $(n=3)$. A mean with different letter indicates that the treatments differed from each other by Tukey's test, $p<0.05$.

also affected by the interaction between factors (Figure 5).

According to the regression equation, it is observed that the plants irrigated with water of the lowest salinity level $\left(0.8 \mathrm{dS} \mathrm{m}^{-1}\right)$ presented a linear decrease of $16.12 \%$ in the $A G R_{G P}$ in the plants fertilized with $115 \%$ of the nitrogen recommendation, compared to those subjected to $70 \%$. This corresponds to a reduction of $0.00390 \mathrm{~mm} \mathrm{~d}^{-1}$ (Figure 5A). However, when the plants were irrigated with water of $4.5 \mathrm{dS} \mathrm{m}^{-1}$, they presented the highest $A G R_{G P}$ $\left(0.0208288 \mathrm{~mm} \mathrm{~d}^{-1}\right)$, when they were fertilized with the dose of $70 \%$ of the fertilization recommendation. This fact is related to the structural functions performed by nitrogen in the plants, which are essential, such as amino acids, proteins, chlorophyll, and nucleic acids (Alves et al., 2012).

The absolute growth rate of the diameter in the rootstock $\left(A G R_{R D}\right)$ of the West Indian cherry plants irrigated with waters with $\mathrm{ECW}$ of $0.8 \mathrm{dS} \mathrm{m}^{-1}$ decreased linearly as the nitrogen doses were raised (Figure 5B), with a reduction of $0.57 \%$ per $15 \%$ increment in the $\mathrm{N}$ 
doses. The plants fertilized with the highest nitrogen dose $(115 \% \mathrm{~N})$ presented a reduction of $1.76 \%\left(0.000367 \mathrm{~mm} \mathrm{~d}^{-1}\right)$ compared to the plants that received $70 \%$ of the $\mathrm{N}$ recommendation. However, when the West Indian cherry plants were irrigated with water with ECW of $4.5 \mathrm{dS} \mathrm{m} \mathrm{m}^{-1}$ and fertilized with a $105 \%$ dose of the $\mathrm{N}$ recommendation,

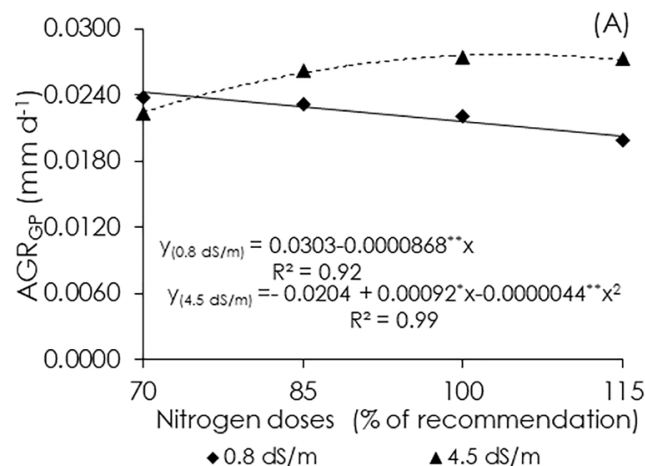

they obtained the highest $A G R_{R D}\left(0.02473 \mathrm{~mm} \mathrm{~d}^{-1}\right)$ and, above this dose, there was a reduction. In this manner, the positive effect of nitrogen may be associated to the $\mathrm{N}$ functions in plant metabolism, and the accumulation of organic solutes raises the capacity for osmotic adjustment by the plants to salinity (Lima et al., 2015).

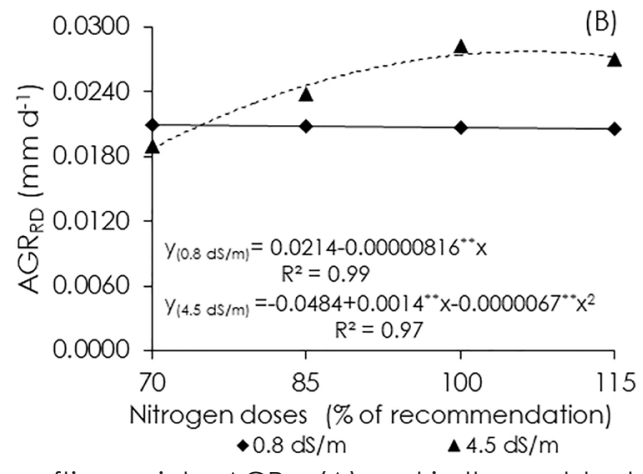

Figure 5. Absolute growth rate of diameter at the grafting point - $A G R_{G P}(A)$ and in the rootstock - $A G R_{R D}(B)$ of the BRS 366 Jaburu West Indian cherry as a function of the interaction between the salinity levels of the irrigation water - ECW and nitrogen doses, in the period from 303 and 650 days after transplantation.

\section{Conclusions}

The synthesis of chlorophyll $a$ and carotenoids in West Indian cherry plants is inhibited by the irrigation with waters with electrical conductivity of $4.5 \mathrm{dS} \mathrm{m}^{-1}$. Nitrogen fertilization in the estimated $\mathrm{N}$ doses of 92 and $80 \%$ reduces the effects of salt stress on the contents of chlorophyll $a$ and $b$ in West Indian cherry plants, at 630 days after transplantation. The increment in nitrogen fertilization increases quadratically the absolute and relative growth rate of the diameter in the rootstock of the West Indian cherry plants under irrigation with saline waters.

\section{Acknowledgments}

To the National Program of Post-Doctorate (PNPD/CAPES/UFCG), for granting the scholarship to the second author and to the National Institute of Science and Technology in Salinity - INCTSal, for funding the project.

\section{References}

Alves, A.N., Gheyi, H.R., Uyeda, C.A., Soares, F.A.L., Nobre, R.G., Cardoso, J.A.F. 2012. Uso de águas salinas e adubação nitrogenada no cultivo da mamoneira BRSenergia. Revista Brasileira de Agricultura Irrigada 6: 151163.

Arnon, D.I. 1949. Copper enzymes in isolated cloroplasts: polyphenoloxidases in Beta vulgaris. Annual Reviews Plant Physiology 24: 1-15.

Assaha, D.V.M., Ueda, A., Yaish, M.W. 2017. The role of $\mathrm{Na}^{+}$ and $\mathrm{K}^{+}$transporters in salt stress adaptation in glycophytes. Frontiers in Physiology 8: 1-19.

Aydin, A., Kant, C., Turan, M. 2012. Humic acid application alleviate salinity stress of bean (Phaseolus vulgaris L.) plants decreasing membrane leakage. African Journal of Agricultural Research 7: 1073-1086.

Benincasa, M.M.P. 2003. Análise de crescimento das plantas, noções básicas. 2.ed. FUNEP, Jaboticabal, Brazil. $1075 \mathrm{p}$.

Cavalcanti, F.J. de A. (Coord.). 2008. Recomendações de adubação para o Estado de Pernambuco: segunda aproximação. 2.ed. IPA, Recife, Brazil. 212 p.

Chen, W., Hou, Z., WU, L., Liang, Y. Wei, C. 2010. Effects of salinity and nitrogen on cotton growth in arid environment. Plant and Soil 326: 61-73.

EMBRAPA - Empresa Brasileira de Pesquisa Agropecuária. 2012. Cultivar acerola BRS 366-Juburu. Embrapa Agroindústria Tropical, Fortaleza, Brazil. (Folder).

Esashika, T., Oliveira, L.A., Moreira, F.W. 2013. Resposta da aceroleira a adubação orgânica, química e foliar num Latossolo da Amazônia Central. Revista de Ciências Agrárias 36: 399-410.

Farooq, M., Hussain, M., Wakeel, A., Siddique, K.H.M. 2015. Salt stress in maize: effects, resistance mechanisms, and management. A review. Agronomy for Sustainable Development 35: 461-481.

Ferreira, D.F. 2014. Sisvar: a guide for its bootstrap procedures in multiple comparisons. Ciência e Agrotecnologia 38: 109-112.

Ferreira, K.S. 2014. Crescimento e acúmulo de nutrientes em mudas de aceroleira adubadas com nitrogênio e potássio. 49f. (Dissertação de Mestrado) - Universidade Federal de São João Del-Rei, São João Del-Rei, Brazil.

Freire, J.L.O., Cavalcante, L.F., Nascimento, R., Rebequi, A.M. 2013. Teores de clorofila e composição mineral foliar do maracujazeiro irrigado com águas salinas e 
biofertilizante. Revista de Ciências Agrárias 36: 57-70.

Gomes, M.A. da C., Suzuki, M.S., Cunha, M. da, Tullii, C.F. 2011. Effect of salt stress on nutrient concentration, photosynthetic pigments, proline and foliar morphology of Salvinia auriculata Aubl. Acta Limnologica Brasiliensia 23: 164-176.

Lima, G.S. de, Dias, A.S., Souza, L. de P., Sá, F.V de S. Gheyi, H.R., Soares, L.A. dos A. 2018. Efeito da água salina e adubação potássica nos pigmentos fotossintéticos, crescimento e produção da aceroleira. Revista Ambiente \& Água 13: 07-12.

Lima, L.A., Oliveira, F. de A., Alves, R. de C., Linhares, P.S.F., Medeiros, A.M.A de, Bezerra, F.M.S. 2015. Tolerância da berinjela à salinidade da água de irrigação. Revista Agroambiente 9: 27-34.

Munns, R., Day, D.A., Fricke, W., Watt, M., Arsova, B., Barkla, B.J., Bose, J., Byrt, C.S., Chen, Z.H., Foster, K.J. Gilliham, M., Henderson, S.W., Jenkins, C.L.D., Kronzucker, H.J., Miklavcic, S.J., Plett, D., Roy, S.J., Shabala, S., Shelden, M.C., Soole, K.L., Taylor, N.L., Tester, M., Wege, S., Wegner, L.H., Tyerman, S.D. 2020. Tansley review energy costs of salt tolerance in crop plants. New Phytologist 225: 10721090.

Oliveira, A.B. de, Alencar, N.L.M., Prisco, J.T., Gomes-Filho, E. 2011. Accumulation of organic and inorganic solutes in $\mathrm{NaCl}$-stressed sorghum seedlings from aged and primed seeds. Scientia Agricola 68: 632-637.

Pereira Filho, J.V., Viana, T.V. de A., Sousa, G.G. de, Chagas, K.L., Azevedo, B.M. de, Pereira, C.C.M. de S. 2019. Physiological responses of lima bean subjected to salt and water stresses. Revista Brasileira de Engenharia Agrícola e Ambiental 23: 959-965.

Richards, L.A. 1954. Diagnosis and improvement of saline and alkali soils. Department of Agriculture, Washington, USA. $160 \mathrm{p}$.

Santos, V.S. dos. 2019. A aceroleira produz a acerola, um fruto rico em vitamina C, ferro, cálcio, fósforo, antocianinas e carotenoides. https://mundoeducacao. bol.vol.com.br/biologia/acerola.htm <Access on 31 Jan. 2019>.

Sousa, A.B.O., Bezerra, M.A., Farias, F.C. 2011. Desenvolvimento inicial do clone BRS 275 de cajueiro sob irrigação com diferentes níveis salinos. Revista Brasileira de Agricultura Irrigada 4: 166-171.

Souto, A.G.L., Cavalcante, L.F., Nascimento, J.A.M., Mesquita, F.O., Lima Neto, A.J. 2013. Comportamento do noni à salinidade da água de irrigação em solo com biofertilizante bovino. Irriga 18: 442-453.

Taiz, L., Zeiger, E. 2013. Fisiologia vegetal. 5.ed. Artmed, Porto Alegre, Brazil. 954 p.

Teixeira, P.C., Donagemma, G.K., Fontana, A. Teixeira, W.G. (org.). 2017. Manual de métodos de análise de solo. 3.ed. Embrapa, Brasília, Brazil. 573 p.
Conflict of Interest Statement: The authors declare that the research was conducted in the absence of any commercial or financial relationships that could be construed as a potential conflict of interest.

All the contents of this journal, except where otherwise noted, is licensed under a Creative Commons Attribution License attribuition-type BY. 